\title{
IgY - turning the page toward passive immunization in COVID-19 infection (Review)
}

\author{
CAROLINA CONSTANTIN ${ }^{1,2}$, MONICA NEAGU $^{1-3}$, TEODORA DIANA SUPEANU ${ }^{4}$, \\ VIORICA CHIURCIU ${ }^{4}$ and DEMETRIOS A. SPANDIDOS ${ }^{5}$
}

\author{
${ }^{1}$ Immunology Laboratory, 'Victor Babes' National Institute of Pathology, 050096 Bucharest; \\ ${ }^{2}$ Department of Pathology, Colentina Clinical Hospital, 020125 Bucharest; ${ }^{3}$ Doctoral School of Biology, Faculty \\ of Biology, University of Bucharest, 050095 Bucharest; ${ }^{4}$ Romvac Company S.A., 077190 Voluntari, Romania; \\ ${ }^{5}$ Laboratory of Clinical Virology, School of Medicine, University of Crete, 71003 Heraklion, Greece
}

Received April 13, 2020; Accepted April 30, 2020

DOI: $10.3892 /$ etm.2020.8704

\begin{abstract}
The world is facing one of the major outbreaks of viral infection of the modern history, however, as vaccine development workflow is still tedious and can not control the infection spreading, researchers are turning to passive immunization as a good and quick alternative to treat and contain the spreading. Within passive immunization domain, raising specific immunoglobulin (Ig)Y against acute respiratory tract infection has been developing for more than 20 years. Far from being an obsolete chapter we will revise the IgY-technology as a new frontier for research and clinic. A wide range of IgY applications has been effectively confirmed in both human and animal health. The molecular particularities of IgY give them functional advantages recommending them as good candidates in this endeavor. Obtaining specific $\operatorname{IgY}$ is sustained by reliable and nature friendly methodology as an alternative for mammalian antibodies. The aria of application is continuously enlarging from bacterial and viral infections to tumor biology. Specific anti-viral IgY were previously tested in several designs, thus its worth pointing out that in the actual COVID-19 pandemic context, respiratory infections need an enlarged arsenal of therapeutic approaches and clearly the roles of IgY should be exploited in depth.
\end{abstract}

\section{Contents}

1. Introduction

2. IgY an established immune-fighter - is there something new on its (bio) applications?

3. Passive immunization in infectious diseases

Correspondence to: Dr Monica Neagu, Immunology Laboratory, 'Victor Babes' National Institute of Pathology, 99-101 Splaiul Independentei, 050096 Bucharest, Romania

E-mail: neagu.monica@gmail.com

Key words: immunoglobulin, IgY, acute respiratory infection, COVID-19
4. Learning from severe acute respiratory syndrome

5. Conclusions and future perspectives

\section{Introduction}

Respiratory tract infections (RTI) are extremely common and in developed countries, RTI account for over $20 \%$ of all medical consultations (1). In children, the figures are even higher. Worldwide, every year, over 1 million children and infants under 5 years die from acute respiratory infections (2), this disease represents in developing countries the cause of death of $30 \%$ of children under five years $(3,4)$. When RTI have an increased frequency, over $60 \%$ of the cases have a primary immunodeficiency in humoral immunity. A recent study has shown that deficiencies in immunoglobulin (Ig) synthesis and secretion are proven in abnormal levels of IgG, $\operatorname{Ig} \mathrm{A}$ and $\operatorname{Ig} M(5)$. Not only Igs are affected, but also other immune molecules. In children diagnosed with RTI decreased levels of proinflammatory cytokines were identified, mainly interferon (IFN)- $\gamma$ (6). IFN-stimulated genes (ISGs) are highly involved in the antiviral immune response (7).

In bacterial infection multidrug-resistant (MDR) processes are involved in the difficult-to-treat pathogens (8-10), but in viral infections this process has just a collateral importance because a substantial proportion of RTI are actually acute viral infections. The treatment of these infections relies on antivirals and on relieving disease symptoms. However, similarly to bacterial infections, antiviral agents would conserve viral proteins, that will induce a selective pressure on the viral particle, leading to development of antiviral resistance $(11,12)$.

As the best 'treatment' is prevention, in viral infections vaccination is the best approach, but the pace of vaccine development is slow and it has to overcome various hurdles, e.g., antigenic variations, low efficacy, short-term immune responses. As we are now faced with one of the major outbreaks of viral infection of the modern history, vaccine development workflow can not control the infection spreading (13). Therefore, novel approaches are tested and designed. One of these novel approaches is passive immunization (14) where mainly polyclonal antibodies derived from several sources 
(e.g., sera of immunized animals, immunized humans, convalescing patients) can be used $(15,16)$. In this case also the use of polyclonal antibodies has some hurdles such as standardization and patient safety. Monoclonal antibodies (mAbs) is the best choice but their production costs is still very high, as an example the high costs of monoclonal antidodies used in melanoma therapies (17). The costs increase further in respiratory infection because there are viral escape mutants that would need additional mAbs (18). Therefore in this complex picture of immunity in viral infection an interesting approach has risen in recent years - the use of specific IgY. IgY is produced by birds, reptiles and amphibians with a function similar to that of mammalian IgGs (19). IgYs are circulating in the sera as IgGs, but in addition they accumulate 100 times more concentrated in the egg yolk and are passed to the developing embryo (20).

IgY antibodies extracted from hen eggs have been used in bacterial (21) and viral infections therapy (22). It has some favorable characteristics: it is well tolerated due to human diet, it can be used in individuals who are allergic to eggs because the purified IgY is depleted of egg albumin (23), it has a good tolerability. Moreover, the systemic administration has shown the capability of specific IgY raised against viruses to protect against actual diseases. For example, in pig model IgY protected against Rotavirus infection (24). Systemic and local administration of IgY in mammals have shown that an anti-IgY antibody response was generated, mainly consisting of the IgG subclass. These reports show that IgY is antigenic but this antibody molecule cannot bind to mammalian Fc receptors, so adverse effects on this route are minimal (25). More than 20 years ago it was shown that in mouse model administration of IgY, purified or not, did not induce an $\operatorname{IgE}$ response, hence no allergic response (26) and due to the fact that IgY does not link to the human complement system or Fc receptors, additional inflammation upon administration is minimal (27). IgY action is to bind to the bacteria or virus, and facilitate the elimination of the agent through the gut preventing bacterial or viral replication and spread (28). Passive immunization with IgY can be given in humans with active infection as they develop a rapid response. Moreover, immature infants or immune-suppressed patients can also benefit from this passive immunization $(29,30)$. IgY has a high content of sialic acid (31), with increased half-life (32) that suggests IgY to have a longer circulating half-life, and hence increased anti-pathogen action and increased efficacy against infections (33).

We aim to highlight in this review that in the quest to find quick and effective anti-viral therapies, specific IgY can be another possibility to fight against viral RTI.

\section{IgY an established immune-fighter - is there something new on its (bio) applications?}

An antigen attack upon host is followed by Igs or antibodies production in humans, process sustained by plasma cells developing thus the humoral immunity (34). Antibodies engage in the fight against the antigen by an array of mechanisms: neutralization, fixation of pathogen, complement activation or acting like receptors on B cell surface (35). Igs have interspecies differences regarding their structural particularities or classes, thus the term IgY comes from egg yolk where this Ig type is produced for assuring immunity in the hen progeny. IgY represents the functional equivalent of human $\operatorname{IgG}(29)$. In the last decade, IgY has gained scientific attention due to its distinctive biological actions largely emerged from its structural particularities (36).

Currently there are several commercial applications where Igs are fully explored in diagnostic and therapy monitoring assays.

Fighting against bacterial infections. Immunization of avian with specific bacterial antigens such as Salmonella sp. would provide a specific IgY against the inductor antigen. Moreover, due its high stability and structural unique features IgY has been applied successfully in diagnostic, prophylactic and therapeutic purposes as well as immunochemical reagents (34).

In addition to chicken models, there are other hands-on and inexpensive models such as the quail model where production of specific IgYs against Salmonella sp. has been recently reported. These quail anti-Salmonella sp. IgYs exhibit a high specificity to their matching immunogens, having the potential to eradicate enterobacterial pathogens. In addition, the oral ingestion of IgYs represent an efficient alternative for annihilation of gastrointestinal pathogens as Salmonella typhimurium and Salmonella enteritidis, bacterial species that raise major concern in health and food industry (37).

IgYs has also been proposed as a strategy for combating infections caused by Pseudomonas aeruginosa known as a common nosocomial pathogen having antibiotic resistance and a frequent infection in acute pneumonia and severely burned patients. A protein called PcrV is a vital part of killing machinery represented by the type III secretion system of $P$. aeruginosa and therefore PcrV is viewed as a target for neutralizing this infectious agent. Thus, recently recombinant PcrV was used for raising specific IgY. These antibodies displayed a protective effect in both acute pneumonia and burn wound models and moreover IgY anti-PcrV has augmented opsonization capacity and bacterial killing activity of host cells (38). In fact the augmentation of phagocytic killing via IgY was previously explored in an in vitro study targeting $P$. aeruginosa infection in cystic fibrosis (CF) patients. IgY against $P$. aeruginosa fulfill their function by opsonizing the pathogen and thus enhancing the neutrophils respiratory burst while further enabling bacterial killing. It was suggested that prophylaxis with anti-P. aeruginosa IgY could lift the innate immunity of CF patients aiding host neutrophils to rapidly clear the bacterial agent (39).

In $\mathrm{CF}$ the principal contributor of pulmonary failure is the chronic infection with $P$. aeruginosa biofilm, which constantly attracts and activates neutrophils sustaining the continuous inflammation. It is suggested that IgY favors bacteria to form aggregates and increase their hydrophobicity enhancing bacterial killing by neutrophils via phagocytosis (40).

Passive immunization with IgY anti- $P$. aeruginosa could reduce the initial airway settlement with $P$. aeruginosa in $\mathrm{CF}$ patients. Thus in a Balb/c murine $P$. aeruginosa pneumonia model administration of specific IgY significantly reduced the bacterial load at $24 \mathrm{~h}$ after infection along with alleviating the clinical symptoms; in addition an inflammatory cytokine pattern was noted revealing the lung inflammation decrease 
suggesting that immune-prophylaxis with anti-P. aeruginosa IgY may also function as an adjuvant to antibiotics in lowering primary colonization of lungs (21). In parasitic diseases the possible role of IgY in early diagnosis and therapeutics has been tackled by attempting to obtain polyclonal IgY against parasitic antigens suitable for immunotherapeutic purposes. Although further studies in animal models are indispensable and obtaining a monoclonal IgY anti-parasitic antigens are envisaged, it became obvious that IgY could stand for immunoassay designing also in parasitology area (41).

In immunodiagnostic methods, IgY is an excellent tool in assays involving mammalian sera, due to the discriminative properties of IgY compared to mammalian IgG. IgY has immunological properties which makes it very distinct from mammalian IgG but at the same time very affordable for a plenty of immunological approaches. Foremost, by lacking the hinge region, IgY is less structurally flexible than IgG and retains a different protein content, these structural differences sustaining the differences in immunological behavior (42). IgY has poor cross-reactivity to mammalian $\mathrm{IgG}$, does not activate the complement system similar to $\operatorname{IgM} / \operatorname{IgG}$ and lacks the reactivity with mammalian Fc receptor (43).

However, there are still incomplete data regarding the three-dimensional structure of Fc-IgY raising the question whether IgY shares a conformational status similar to IgM and $\mathrm{IgE}$ whose Fc regions are significantly flexible. However, the evolutionary distance between mammals and birds made possible the feasible generation of IgY against conserved mammal proteins. Thus, the molecular particularities of IgY raised several functional advantages recommending $\operatorname{IgY}$ as a versatile tool in biotechnological research, diagnostics and therapeutics (29). One very practical utility is that IgY can be used to generate a specific antibody when an antigen comes in small amounts and additionally is low immunogenic in mammals host (44).

IgY can be generated at low-costs in considerable amounts through an ecologically friedly approach because it is produced in egg yolk so no additional procedures on animals are needed. There are several IgY isolation methods available, mostly based on precipitation from egg extracts using ammonium sulfate or polyethylene glycol although protein impurities still remains in the sample of interest, in addition to time consuming and complexity required $(45,46)$. Chromatographic methods have become very popular in recent years because this methodology generates highly active pure products useful for biomedical applications. A study published in 2020 reports IgY fragment separations by ion exchange column using DEAE-Sepharose leading to Fab and Fc fractions of high purity (88.7 and 90.1\%, namely) and intact activity rendering them easily used for medical purposes (47).

Usually, antibodies and/or their active fragments produced in mammals are engaged in diagnostic tests. However, due to animal welfare concerns, technical advantages and the high cost of production, alternatives to the production of antibodies in mammals have been investigated (48).

A constant goal for all current approaches involving IgY applications is to continuously optimize the production and purification of IgY antibodies from egg yolk to achieve high quantities and high active products for research and commercial use.
The most exploited immunoassay format with IgY remains the ELISA platform. In research as well as in clinic, one of the most effective and reliable method for rapid detection remains ELISA which is a versatile, flexible and sensitive method helpful in monitoring various pathologies including infectious diseases. Although IgG is the 'weapon of choice' in designing such detection formats, in recent years IgY started to replace IgG because this molecule could be easily obtained, through a non-invasive way (basically extracted and purified from egg yolk of chickens immunized with recombinant proteins of interest), in adequate amounts and at lower costs than IgG.

IgY-based ELISA protocols retain all the features related to steps, reagents and applications of classic ELISA formats as IgY molecule can be enzymatically labeled (e.g., with horseradish peroxidase) and further applied in a wide range of immunoassay assessments such as bacterial toxins (49) or tumor antigen detection for cancer diagnosis $(50,51)$.

It is truly noticeable how versatile the use of IgY could be related to area of application, from viruses and bacteria to tumor antigens detection and quantification (42). Thus, diagnosis of cholera is somewhat an intricate attempt. Therefore, a recent study proposed $\mathrm{IgY}$ for targeting two proteins contained by the outer membrane of $V$. cholera (protein $\mathrm{W}$ and cytotoxin B). The study proposed two sensitive and specific sandwich ELISA formats, with no cross-reactivity with other bacteria. It was suggested that these IgY based ELISAs could constitute a rapid and specific detection tool for assessing $V$. cholera in different biological samples (52).

The use of IgY instead of mouse monoclonal IgG has the advantage of limiting the risk of false positive results as well as the reduced costs of the test. For example, an IgY-based sandwich ELISA was developed to quantify the total PSA level in human serum as an alternative to commercially available in vitro diagnosis tests (53).

Taking into account the latest concerns raised by respiratory infections of viral origin IgY might act as a very promising detection agent in this area. Thus, recent studies in swine model suggest that IgY molecule could bind specifically to viral nucleoprotein of influenza virus, which is known for exerting a key role in viral replication and therefore emphasizing the IgY effectiveness for influenza virus diagnosis $(48,54)$.

Is there some spare room for other methodologies regarding IgY characterization in the last decade? As already mentioned, IgY purification is currently achieved by conventional precipitation methods with ammonium sulphate or PEG and by chromatographic procedures. Sequential precipitation with $31 \%$ ammonium sulfate and $12 \%$ polyethylene glycol (PEG) produces IgY antibodies with above $95 \%$ purity without any loss in immunoreactivity (55).

Additional procedures of purification could be added to the separation methodologies, such as high-resolution chromatography accomplished for instance by multi-column systems such as NGC scout Bio-Rad system. Especially, but not restricted to mAbs, this system provides certain advantages over conventional chromatographic columns in terms of automatization, reproducibility and accessibility. During the process of obtaining biomolecules intended for biomedical application, high purity and intact functionality are the first considerations. Moreover a multi-column automated system 
A

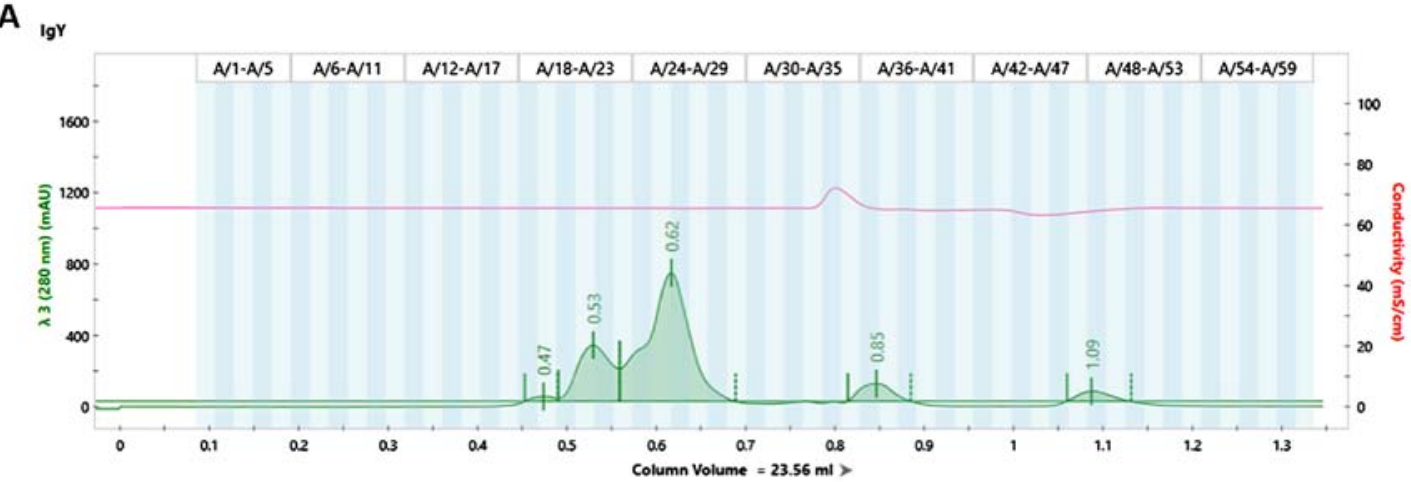

B

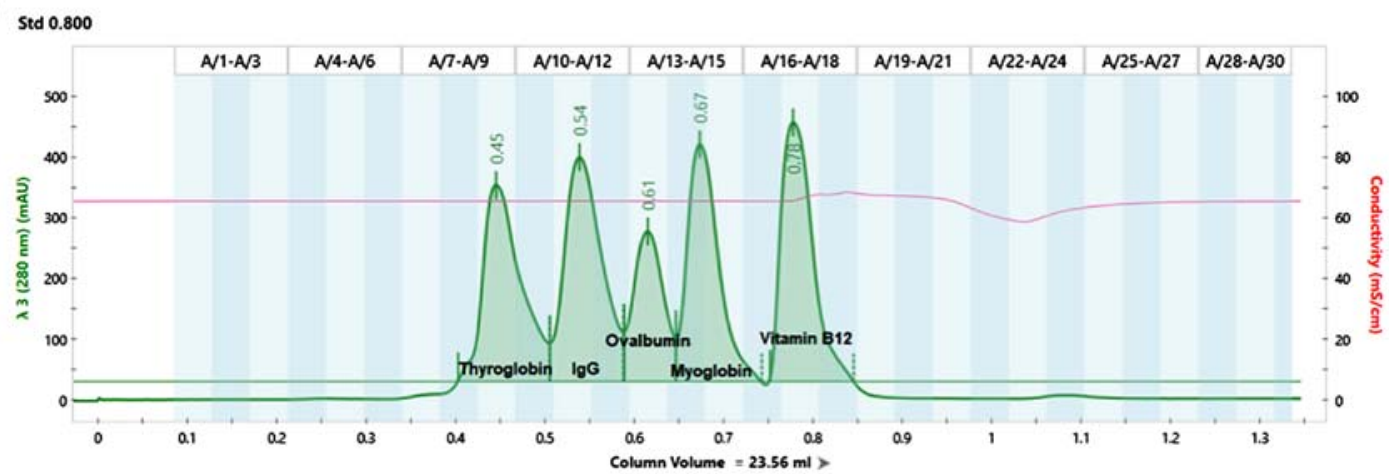

Figure 1. NGC Chromatograms of IgY extract isolated from hen egg yolk in comparison to standard protein cocktail. (A) Hen yolk egg IgY extract at $1 \mathrm{mg} / \mathrm{ml}$ concentration; (B) Standard protein cocktail for molecular weight identification. Column - size exclusion ENrich SEC 650 , PBS elution, flow at 0.8 ml/min, absorbance registered $280 \mathrm{~nm}$. IgY, immunoglobulin Y.

could resolve several steps of purification in a single run, such as separation by affinity purification of a particular compound from original matrix, size exclusion to resolve aggregates and finally obtaining the product of interest with undamaged structure and function (56). By choosing the appropriate column the compound is loaded, purified and analyzed in a continuous run. High purification is further explored for designing platforms in which pathogens could be discriminated or when ELISA type platform are constructed intended for research or diagnosis.

An example of analyzing an IgY extract isolated from hen egg yolk by the Romanian Company Romvac S.A. using NGC scout Bio-Rad system is presented in Fig. 1.

\section{Passive immunization in infectious diseases}

Passive immunization as general process. Passive immunization refers to administering already mature antibodies (Igs) in an attempt to rapidly overcome an infectious disease (57). Passive immunity can represent a natural phenomenon and/or can be artificially induced (58).

The natural passive immunity consists of maternal antibodies that are transferred to the offspring inducing protection before the offspring's self-immunity is built up. In birds, passive imunity is sustained by the IgY from the egg yolk which enters into the developing embryo $(59,60)$ and hence sustaining the first 2 weeks immunity in chickens, at the time when they start to build up their own immunity (61). In mammals passive immunity is sustained by maternal antibodies that are transferred to the fetus through the placenta, in humans this process is active especially during the last 3 months of pregnancy. Then the passive immunity is sustained by milk that also contains antibodies (62).

Artificially induced passive immunity is sustained by transferring antibodies by systemic, intravenous, or oral routes. Passive immunity is limited in time, thus, to sustain this immunity, preformed antibodies should be re-introduced (63).

A low-cost and rapid technology to obtain large scale passive immunity antibodies are IgY from egg yolk via hyperimmunization of chickens. Briefly this process involves hen immunization with specific antigens with a specific time schedule so that specific IgYs accumulate in the egg yolks. Afterwards, these IgY are extracted $(55,64)$. Passive immunization has a history of more than 100 years and has been used in both humans and animals $(67,68)$. Over 20 years ago, one of the first reports was published showing that intranasal antibody prophylaxis, was successful against viral respiratory infections in animal models [e.g., against respiratory syncytial virus (RSV), influenza virus, Sendai virus], and entered human clinical trials for influenza A and B viruses, Coxsackie virus, and rhinoviruses (67). Since then only non-viral IgY applications have been published such as oral administration of IgY preventing or treating diseases induced by Streptococcus mutans (dental carries), E. coli-diarrhea, gastritis (H.pylori), periodontitis (P.gingivalis) and oral candidiasis (C.albicans) infant rotavirus diarrhea (23). Rotavirus-induced diarrhea containing IgY (Rotamix IgY) was efficient in pediatric patients diagnosed with non-cholera enteric pathogen and was proven as a good adjuvant for the management of acute diarrhea (68). Therefore, IgY raised for specific viral respiratory infections should enter the spotlight again. 
IgY in passive immunization. IgY utilization in passive immunization has several advantages. Obtaining IgY from birds is ecologically friendly, the extract does not induce specific resistance and/or side effects and due to their specificity would not affect beneficial microbial population of the host.

Finally, if used as therapy in poultry and livestock IgY does not stay in the meat that is destined to human consumption as antibiotics do (69).

Using specific IgY in passive immunization is not age restricted, it can be applied to a wide range of ages, to a wide array of individuals characterized by patophysiological conditions, e.g., women in special conditions like pregnancy and/or immunodeficient patients.

IgY antibodies are naturally non-toxic and when lyophilized they can be stored in regular $4^{\circ} \mathrm{C}$ or even at room temperature without losing their efficacy. Production costs are much lower when compared to standard mAbs and/or vaccines. Then storing can be done for months and transportation is thus facilitated in comparison to other biologicals (70). If not extracted the composition of IgY stored in eggs remains unchanged for at least 1 year at $4^{\circ} \mathrm{C}(71)$. The product, IgY is collected from eggs and, therefore, does not impede the animal welfare.

From a molecular point of view, IgY has increased binding avidity for the antigens that generated them in comparison to mammalian $\operatorname{IgG}$ (72). Due to the evolutionary distance between mammals and birds IgY can be produced more easily against conserved mammalian molecules than IgG antibodies (73). For IgY generation a lower antigen load is necessary to induce the specific immune response (69).

For mass production, as the production of eggs for human consumption is already carried out on an industrial scale the production of eggs containing specific IgY already has its industrial backbone (74). One chicken can produce specific IgY of approximately $22 \mathrm{~g} /$ year (45).

\section{Learning from severe acute respiratory syndrome}

Almost 20 years ago, coronaviruses (CoVs) were known to cause disease only in vertebrates but then, the severe acute respiratory syndrome (SARS)-CoV outburst in China showed the medical world that nature still has unknown paths (75). The disease spread rapidly worldwide, causing under 10,000 infections with a $10 \%$ mortality rate $(76,77)$. Through the SARS epidemy in China, passive immunization that used sera from recovered SARS patients offered positive results (78). $\operatorname{IgY}$ preparations were obtained with anti-SARS coronavirus action after isolation from egg yolk obtained from pathogen-free chickens immunized with SARS coronavirus antigen (78). It was reported that the obtained $\operatorname{IgY}$ had both high purity and biological activity. In cells model, the obtained IgY neutralized the SARS coronavirus. The preparation was stable upon lyophilization, that gave the product good manufacturing qualities (78). Anti-SARS IgY produced upon this procedure is a good candidate for anti SARS-CoV therapy. The authors stated that in case of an outbreak, a rapid intervention can be sustained by production of IgY antibodies. The production of an IgY antibody takes 1.5 months from hens vaccination to IgY production, so until a vaccination for an eventual outbreak is put in use, this rapid response can fulfill an urgent medical 
need. Moreover even when a proper vaccination is established, using this type of passive immunizations can significantly increase the control of the epidemic (78).

In 2007 a post-SARS outburst paper has shown that there is SARS-CoV viral reservoir that is actually a biological bomb waiting to explode (79) and now, after 15 years we are facing the biggest pandemic since the Spanish Flu in 1918. The medical world is 'fast forwarding' research and translating research results to bedside. In this race, information changes almost in each hour. At present time, in the race to obtaining quickly a vaccine there are 44 products with 2 in clinical trial phase I (80), but these data will be obsolete in the forthcoming month. Nevertheless, until vaccination enters the application stages there are several steps and phases to be taken. Therefore, probably by the end of 2020 there will be the most accelerated approved vaccine. Alternative methods to overcome the outbreak and to therapeutically sustain infected patients are urgently needed. Passive immunization with plasma from recovered patients was already approved in USA (81). In this picture of passive immunization therapy IgY can have a future role.

Table I summarizes the main studies that used anti-viral respiratory infection IgY emphasizing on the experimental models, whether cellular or animal models.

\section{Conclusions and future perspectives}

Menacing viruses causing pandemics such as COVID-19 claim imperative future measures shaped in therapeutics and novel vaccines. Large-scale and coordinated effort are needed to minimize the impact of these threats on human health $(87,88)$. Joining these efforts, additional therapeutics open the perspective of using passive immunization with IgY on large scale as adjuvant therapy in viral respiratory infection. This endeavor should focus on aspects of increased production, improved hen immunization protocols, improved IgY extraction and increased antibody yield. Another point to be taken into consideration in the future is that chicken IgY have good monoclonality, therefore are more specific and have higher affinity in comparison to the ones obtained from immunizing mammals (89). As compared to IgGs, obtaining genetically engineered single chain fragment variable for IgY (IgY-scFv) is easier as these fragments were already implemented in diagnostics and therapy $(29,90)$.

Therefore, using specific IgY in viral respiratory infections have good premise and can be expanded to other infectious diseases.

In conclusion, far from being an obsolete chapter in immunodiagnostics, the IgY-technology is revised as a new frontier for research and clinic as already a wide range of IgY applications has been effectively confirmed in both human and animal health. The molecular particularities of IgY give them functional advantages recommending $\operatorname{IgY}$ as a versatile tool in biotechnological research, diagnostics and therapeutics. The main advantage is that IgY methodology is a reliable and nature friendly alternative for obtaining mammalian antibodies, as it is a non-invasive procedure. The aria of application is continuously enlarging from bacterial and viral infections to tumor biology. Specific anti-viral IgY has already been tested in several designs, thus it is worth pointing out that in the actual COVID-19 pandemic context, respiratory infections need an enlarged arsenal of therapeutic approaches and definitely $\operatorname{IgY}$ roles should be exploited in depth.

\section{Acknowledgements}

Authors would like to thank Dr Alexandra Livescu and Dr Ovidiu Geicu (Dialab Solutions) for their invaluable technical assistance in NGC scout Bio-Rad system separations.

\section{Funding}

This study was supported by IntelBiomed project, SMIS code 105631, ID: P_40_197, Grant No. 52/2016.

\section{Availability of data and materials}

The information analyzed during the current study is available from the corresponding author on reasonable request.

\section{Authors' contributions}

All authors substantially contributed to the writing and revision of the work and read and approved the final manuscript.

\section{Ethics approval and consent to participate}

Not applicable.

\section{Patient consent for publication}

Not applicable

\section{Competing interests}

DAS is the Editor-in-Chief for the journal, but had no personal involvement in the reviewing process, or any influence in terms of adjudicating on the final decision, for this article. The other authors declare that they have no competing interests.

\section{References}

1. Bryce J, Boschi-Pinto C, Shibuya K and Black RE; WHO Child Health Epidemiology Reference Group: WHO estimates of the causes of death in children. Lancet 365: 1147-1152, 2005.

2. Qazi S, Aboubaker S, MacLean R, Fontaine O, Mantel C, Goodman T, Young M, Henderson P and Cherian T: Ending preventable child deaths from pneumonia and diarrhoea by 2025. Development of the integrated Global Action Plan for the Prevention and Control of Pneumonia and Diarrhoea. Arch Dis Child 100 (Suppl 1): S23-S28, 2015.

3. Ujunwa $F$ and Ezeonu C: Risk factors for acute respiratory tract infections in under-five children in enugu Southeast Nigeria. Ann Med Health Sci Res 4: 95-99, 2014.

4. Munteanu AN, Surcel M, Constantin C and Neagu M: Syncytial virus respiratory infections in children - immunological aspects. Rev Biol Biomed Sci 2: 29-39, 2019.

5. Pasternak G, Lewandowicz-Uszyńska A and Pentoś K: Disorders of humoral immunity in children with IgG subclass deficiency and recurrent respiratory infections. Adv Exp Med Biol 1108: 99-106, 2018

6. Ivanova ON, Argunova EF, Alekseev SN, Ystugina TV, Varfolomeev AR, Troev IP, Kononova IV and Egorova VE: Adaptive mechanisms of the immune system in children in far north. Wiad Lek 68: 534-536, 2015. 
7. Liu Z, Qin Q, Wu C, Li H, Shou J, Yang Y, Gu M, Ma C, Lin W, Zou Y, et al: Downregulated NDR1 protein kinase inhibits innate immune response by initiating an miR146a-STAT1 feedback loop. Nat Commun 9: 2789, 2018.

8. Mogayzel PJ Jr, Naureckas ET, Robinson KA, Brady C, Guill M, Lahiri T, Lubsch L, Matsui J, Oermann CM, Ratjen F, et al; Cystic Fibrosis Foundation Pulmonary Clinical Practice Guidelines Committee: Cystic Fibrosis Foundation pulmonary guideline. pharmacologic approaches to prevention and eradication of initial Pseudomonas aeruginosa infection. Ann Am Thorac Soc 11: 1640-1650, 2014

9. Mogayzel PJ Jr, Naureckas ET, Robinson KA, Mueller G Hadjiliadis D, Hoag JB, Lubsch L, Hazle L, Sabadosa K and Marshall B; Pulmonary Clinical Practice Guidelines Committee: Cystic fibrosis pulmonary guidelines. Chronic medications for maintenance of lung health. Am J Respir Crit Care Med 187: 680-689, 2013

10. Pasteur MC, Bilton D and Hill AT; British Thoracic Society Bronchiectasis non-CF Guideline Group: British Thoracic Society guideline for non-CF bronchiectasis. Thorax 65 (Suppl 1): i1-i58, 2010.

11. McCaskill JL, Ressel S, Alber A, Redford J, Power UF, Schwarze J, Dutia BM and Buck AH: Broad-spectrum inhibition of respiratory virus infection by MicroRNA mimics targeting p38 MAPK signaling. Mol Ther Nucleic Acids 7: 256-266, 2017.

12. Ge Y and Sun S: Estimation of coronavirus disease case-fatality risk in real time. Emerg Infect Dis: Apr 21, 2020 (Epub ahead of print).

13. Corti D, Passini N, Lanzavecchia A and Zambon M: Rapid generation of a human monoclonal antibody to combat Middle East respiratory syndrome. J Infect Public Health 9: 231-235, 2016.

14. Sparrow E, Friede M, Sheikh M and Torvaldsen S: Therapeutic antibodies for infectious diseases. Bull World Health Organ 95: 235-237, 2017.

15. Graham BS and Ambrosino DM: History of passive antibody administration for prevention and treatment of infectious diseases. Curr Opin HIV AIDS 10: 129-134, 2015.

16. Shen C, Wang Z, Zhao F, Yang Y, Li J, Yuan J, Wang F, Li D, Yang M, Xing L, et al: Treatment of 5 critically ill patients with COVID-19 with convalescent plasma. JAMA: Mar 27, 2020 (Epub ahead of print)

17. Ancuceanu R and Neagu M: Immune based therapy for melanoma. Indian J Med Res 143: 135-144, 2016.

18. Casadevall A, Dadachova E and Pirofski LA: Passive antibody therapy for infectious diseases. Nat Rev Microbiol 2: 695-703, 2004.

19. Warr GW, Magor KE and Higgins DA: IgY: Clues to the origins of modern antibodies. Immunol Today 16: 392-398, 1995.

20. Carlander D, Stålberg J and Larsson A: Chicken antibodies: A clinical chemistry perspective. Ups J Med Sci 104: 179-189, 1999.

21. Thomsen K, Christophersen L, Bjarnsholt T, Jensen PO, Moser C and Høiby N: Anti-Pseudomonas aeruginosa IgY antibodies augment bacterial clearance in a murine pneumonia model. J Cyst Fibros 15: 171-178, 2016.

22. Nguyen HH, Tumpey TM, Park HJ, Byun Y-H, Tran LD, Nguyen VD, Kilgore PE, Czerkinsky C, Katz JM, Seong BL, et al: Prophylactic and therapeutic efficacy of avian antibodies against influenza virus H5N1 and H1N1 in mice. PLoS One 5: e10152, 2010.

23. Rahman S, Van Nguyen S, Icatlo FC Jr, Umeda K and Kodama Y: Oral passive IgY-based immunotherapeutics: A novel solution for prevention and treatment of alimentary tract diseases. Hum Vaccin Immunother 9: 1039-1048, 2013.

24. Vega CG, Bok M, Vlasova AN, Chattha KS, Fernández FM, Wigdorovitz A, Parreño VG, Saif LJ and Salmon H: IgY antibodies protect against human Rotavirus induced diarrhea in the neonatal gnotobiotic piglet disease model. PLoS One 7: e42788, 2012.

25. Torché AM, Le Dimna M, Le Corre P, Mesplède A, Le Gal S, Cariolet $\mathrm{R}$ and Le Potier MF: Immune responses after local administration of IgY loaded-PLGA microspheres in gut-associated lymphoid tissue in pigs. Vet Immunol Immunopathol 109: 209-217, 2006

26. Akita E, Jang C, Kitts D and Nakai S: Evaluation of allergenicity of egg yolk immunoglobulin $\mathrm{Y}$ and other egg proteins by passive cutaneous anaphylaxis. Food Agric Immunol 11: 191-201, 1999.

27. Kovacs-Nolan J and Mine Y: Egg yolk antibodies for passive immunity. Annu Rev Food Sci Technol 3: 163-182, 2012.
28. Xu Y, Li X, Jin L, Zhen Y, Lu Y, Li S, You J and Wang L: Application of chicken egg yolk immunoglobulins in the control of terrestrial and aquatic animal diseases: A review. Biotechnol Adv 29: 860-868, 2011.

29. Zhang X, Calvert RA, Sutton BJ and Doré KA: IgY: A key isotype in antibody evolution. Biol Rev Camb Philos Soc 92: 2144-2156, 2017

30. Muller S, Schubert A, Zajac J, Dyck T and Oelkrug C: IgY antibodies in human nutrition for disease prevention. Nutr J 14: 109, 2015.

31. Gilgunn S, Millán Martín S, Wormald MR,Zapatero-Rodríguez J, Conroy PJ, O'Kennedy RJ, Rudd PM, Saldova R and Mondelli MU: Comprehensive N-Glycan profiling of avian immunoglobulin Y PLoS One 11: e0159859, 2016.

32. Liu L: Antibody glycosylation and its impact on the pharmacokinetics and pharmacodynamics of monoclonal antibodies and Fc-fusion proteins. J Pharm Sci 104: 1866-1884, 2015.

33. Abbas AT, El-Kafrawy SA, Sohrab SS and Azhar EIA: IgY antibodies for the immunoprophylaxis and therapy of respiratory infections. Hum Vaccin Immunother 15: 264-275, 2019.

34. Amro WA, Al-Qaisi W and Al-Razem F: Production and purification of IgY antibodies from chicken egg yolk. J Genet Eng Biotechnol 16: 99-103, 2018.

35. Hoffman W, Lakkis FG and Chalasani G: B cells, antibodies, and more. Clin J Am Soc Nephrol 11: 137-154, 2016.

36. Michael A, Meenatchisundaram S, Parameswari G, Subbraj T, Selvakumaran R and Ramalingam S: Chicken egg yolk antibodies (IgY) as an alternative to mammalian antibodies. Indian J Sci Technol 3: 468-474, 2010

37. Esmailnejad A, Abdi-Hachesoo B, Hosseini Nasab E and Shakoori M: Production, purification, and evaluation of quail immunoglobulin Y against Salmonella typhimurium and Salmonella enteritidis. Mol Immunol 107: 79-83, 2019.

38. Ranjbar M, Behrouz B, Norouzi F and Mousavi Gargari SL: Anti-PcrV IgY antibodies protect against Pseudomonas aeruginosa infection in both acute pneumonia and burn wound models. Mol Immunol 116: 98-105, 2019.

39. Thomsen K, Christophersen L, Jensen PØ, Bjarnsholt T, Moser C and Høiby N: Anti-Pseudomonas aeruginosa IgY antibodies promote bacterial opsonization and augment the phagocytic activity of polymorphonuclear neutrophils. Hum Vaccin Immunother 12: 1690-1699, 2016.

40. Thomsen K, Christophersen L, Bjarnsholt T, Jensen PØ, Moser C and Høiby N: Anti-Pseudomonas aeruginosa IgY antibodies induce specific bacterial aggregation and internalization in human polymorphonuclear neutrophils. Infect Immun 83: 2686-2693, 2015.

41. Thirumalai D, Visaga Ambi S, Vieira-Pires RS, Xiaoying Z, Sekaran S and Krishnan U: Chicken egg yolk antibody (IgY) as diagnostics and therapeutics in parasitic infections - A review. Int J Biol Macromol 136: 755-763, 2019.

42. Pereira EPV, van Tilburg MF, Florean EOPT and Guedes MIF: Egg yolk antibodies (IgY) and their applications in human and veterinary health: A review. Int Immunopharmacol 73: 293-303, 2019.

43. Dunkelberger JR and Song WC: Complement and its role in innate and adaptive immune responses. Cell Res 20: 34-50, 2010.

44. Munhoz LS, Vargas GDÁ, Fischer G, Lima M, Esteves PA and Hübner SO: Avian IgY antibodies: Characteristics and applications in immunodiagnostic. Cienc Rural 44: 153-160, 2014.

45. Pauly D, Chacana PA, Calzado EG, Brembs B and Schade R: IgY technology: Extraction of chicken antibodies from egg yolk by polyethylene glycol (PEG) precipitation. J Vis Exp 2011: 3084, 2011.

46. Polanowski A, Zabłocka A, Sosnowska A, Janusz M and Trziszka T: Immunomodulatory activity accompanying chicken egg yolk immunoglobulin Y. Poult Sci 91: 3091-3096, 2012

47. Zhou X, Wang Y, Ahn DU and Cai Z: An easy and simple separation method for $\mathrm{Fc}$ and $\mathrm{Fab}$ fragments from chicken immunoglobulin Y (IgY). J Chromatogr B Analyt Technol Biomed Life Sci 1141: 122011, 2020.

48. da Silva MC, Schaefer R, Gava D, Souza CK, da Silva Vaz I Jr, Bastos AP and Venancio EJ: Production and application of anti-nucleoprotein IgY antibodies for influenza A virus detection in swine. J Immunol Methods 461: 100-105, 2018.

49. Nagaraj S, Ramlal S, Kingston J and Batra HV: Development of IgY based sandwich ELISA for the detection of staphylococcal enterotoxin G (SEG), an egc toxin. Int J Food Microbiol 237: 136-141, 2016. 
50. Grzywa R, Łupicka-Słowik A, Walczak M, Idzi M, Bobrek K, Boivin S, Gaweł A, Stefaniak T, Oleksyszyn J and Sieńczyk M: Highly sensitive detection of cancer antigen 15-3 using novel avian IgY antibodies. ALTEX 31: 43-52, 2014

51. Ferreira A Jr, Santos JP, Bassi PB, Bittar JFF and Bittar ER: IgY-technology applied to studies of toxoplasma gondii infection. In: Toxoplasmosis. IntechOpen, 2017. https://www.intechopen. com/books/toxoplasmosis/igy-technology-applied-to-studies-oftoxoplasma-gondii-infection. Accessed June 14, 2017.

52. Bayat M, Khabiri A and Hemati B: Development of IgY-based sandwich ELISA as a robust tool for rapid detection and discrimination of toxigenic Vibrio cholerae. Can J Infect Dis Med Microbiol 2018: e4032531, 2018.

53. Łupicka-Słowik A, Grzywa R, Leporowska E, Procyk D, Oleksyszyn J and Sieńczyk M: Development and evaluation of an immunoglobulin Y-based ELISA for measuring prostate specific antigen in human serum. Ann Lab Med 39: 373-380, 2019.

54. Eisfeld AJ, Neumann G and Kawaoka Y: At the centre: Influenza A virus ribonucleoproteins. Nat Rev Microbiol 13: 28-41, 2015.

55. Rajic A, Stehmann C, Autelitano DJ, Vrkic AK, Hosking CG, Rice GE and Ilag LL: Protein depletion using IgY from chickens immunised with human protein cocktails. Prep Biochem Biotechnol 39: 221-247, 2009.

56. Elms P: Advantages of multidimensional (Multi-D) chromatography using the $\mathrm{NGC}^{\mathrm{TM}}$ chromatography system over traditional sequential chromatography. Bulletin 6694. Bio-Rad Laboratories, Inc., Hercules, CA, 2016.

57. Casadevall A and Scharff MD: Return to the past: The case for antibody-based therapies in infectious diseases. Clin Infect Dis 21: $150-161,1995$

58. Baxter D: Active and passive immunity, vaccine types, excipients and licensing. Occup Med (Lond) 57: 552-556, 2007.

59. Patterson R, Youngner JS, Weigle WO and Dixon FJ: The metabolism of serum proteins in the hen and chick and secretion of serum proteins by the ovary of the hen. J Gen Physiol 45 501-513, 1962

60. Rose ME, Orlans E and Buttress N: Immunoglobulin classes in the hen's egg: Their segregation in yolk and white. Eur J Immunol 4: 521-523, 1974.

61. Hamal KR, Burgess SC, Pevzner IY and Erf GF: Maternal antibody transfer from dams to their egg yolks, egg whites, and chicks in meat lines of chickens. Poult Sci 85: 1364-1372, 2006.

62. Helmenstine AM: An introduction to active immunity and passive immunity. ThoughtCo, 2019. https://www.thoughtco com/active-immunity-and-passive-immunity-4134137. Accessed April 29, 2020.

63. Chalghoumi R, Marcq C, Théwis A, Portetelle D and Beckers Y: Effects of feed supplementation with specific hen egg yolk antibody (immunoglobin Y) on Salmonella species cecal colonization and growth performances of challenged broiler chickens. Poult Sci 88: 2081-2092, 2009

64. Gadde U, Rathinam T and Lillehoj HS: Passive immunization with hyperimmune egg-yolk IgY as prophylaxis and therapy for poultry diseases - A review. Anim Health Res Rev 16: 163-176, 2015.

65. Eibl MM: History of immunoglobulin replacement. Immunol Allergy Clin North Am 28: 737-764, viii, 2008.

66. Hsu JL and Safdar N: Polyclonal immunoglobulins and hyperimmune globulins in prevention and management of infectious diseases. Infect Dis Clin North Am 25: 773-788, 2011.

67. Weltzin R and Monath TP: Intranasal antibody prophylaxis for protection against viral disease. Clin Microbiol Rev 12: 383-393, 1999.

68. Rahman S, Higo-Moriguchi K, Htun KW, Taniguchi K, Icatlo FC Jr, Tsuji T, Kodama Y, Van Nguyen S, Umeda K, Oo HN, et al: Randomized placebo-controlled clinical trial of immunoglobulin $\mathrm{Y}$ as adjunct to standard supportive therapy for rotavirus-associated diarrhea among pediatric patients. Vaccine 30: 4661-4669, 2012

69. Li X, Wang L, Zhen Y, Li S and Xu Y: Chicken egg yolk antibodies (IgY) as non-antibiotic production enhancers for use in swine production: A review. J Anim Sci Biotechnol 6: 40, 2015.

70. Thu HM, Myat TW, Win MM, Thant KZ, Rahman S, Umeda K, Nguyen SV, Icatlo FC Jr, Higo-Moriguchi K, Taniguchi K, et al: Chicken egg yolk antibodies (IgY) for prophylaxis and treatment of rotavirus diarrhea in human and animal neonates: A concise review. Han-gug Chugsan Sigpum Hag-hoeji 37: 1-9, 2017.

71. Jensenius JC, Andersen I, Hau J, Crone M and Koch C: Eggs: Conveniently packaged antibodies. Methods for purification of yolk IgG. J Immunol Methods 46: 63-68, 1981.
72. Ikemori Y, Peralta RC, Kuroki M, Yokoyama H and Kodama Y: Research note: Avidity of chicken yolk antibodies to enterotoxigenic Escherichia coli fimbriae. Poult Sci 72: 2361-2365, 1993.

73. Gassmann M, Thömmes P, Weiser T and Hübscher U: Efficient production of chicken egg yolk antibodies against a conserved mammalian protein. FASEB J 4: 2528-2532, 1990.

74. Sharma JM: Introduction to poultry vaccines and immunity. Adv Vet Med 41: 481-494, 1999.

75. Perlman S and Netland J: Coronaviruses post-SARS: Update on replication and pathogenesis. Nat Rev Microbiol 7: 439-450, 2009.

76. Rota PA, Oberste MS, Monroe SS, Nix WA, Campagnoli R, Icenogle JP, Peñaranda S, Bankamp B, Maher K, Chen MH, et al: Characterization of a novel coronavirus associated with severe acute respiratory syndrome. Science 300: 1394-1399, 2003.

77. Drosten C, Günther S, Preiser W, van der Werf S, Brodt HR, Becker S, Rabenau H, Panning M, Kolesnikova L, Fouchier RAM, et al: Identification of a novel coronavirus in patients with severe acute respiratory syndrome. N Engl J Med 348: 1967-1976, 2003

78. Fu CY, Huang H, Wang XM, Liu YG, Wang ZG, Cui SJ, Gao HL, Li Z, Li JP and Kong XG: Preparation and evaluation of anti-SARS coronavirus IgY from yolks of immunized SPF chickens. J Virol Methods 133: 112-115, 2006.

79. Cheng VC, Lau SK, Woo PC and Yuen KY: Severe acute respiratory syndrome coronavirus as an agent of emerging and reemerging infection. Clin Microbiol Rev 20: 660-694, 2007.

80. Gavi, The Vaccine Alliance: The latest in the COVID-19 vaccine race. https://www.gavi.org/vaccineswork/covid-19-vaccine-race. Accessed March 24, 2020.

81. Mail Online: FDA approves first US coronavirus treatment: Doctors across the US can now treat the sickest Americans with plasma from recovered patients. https://www.dailymail.co.uk/ health/article-8147631/Can-blood-coronavirus-survivors-treatnewly-ill.html. Accessed March 24, 2020.

82. Tsukamoto M, Hiroi S, Adachi K, Kato H, Inai M, Konishi I, Tanaka M, Yamamoto R, Sawa M, Handharyani E, et al: Antibodies against swine influenza virus neutralize the pandemic influenza virus A/H1N1. Mol Med Rep 4: 209-214, 2011.

83. Wen J, Zhao S, He D, Yang Y, Li Y and Zhu S: Preparation and characterization of egg yolk immunoglobulin $Y$ specific to influenza B virus. Antiviral Res 93: 154-159, 2012.

84. Yang YE, Wen J, Zhao S, Zhang K and Zhou Y: Prophylaxis and therapy of pandemic H1N1 virus infection using egg yolk antibody. J Virol Methods 206: 19-26, 2014

85. Wallach MG, Webby RJ, Islam F, Walkden-Brown S, Emmoth E, Feinstein $\mathrm{R}$ and Gronvik KO: Cross-protection of chicken immunoglobulin $\mathrm{Y}$ antibodies against $\mathrm{H} 5 \mathrm{~N} 1$ and $\mathrm{H} 1 \mathrm{~N} 1$ viruses passively administered in mice. Clin Vaccine Immunol 18 1083-1090, 2011

86. Ferella A, Bellido D, Chacana P and Wigdorovitz A: DusSantos MJ and Mozgovoj MV: Chicken egg yolk antibodies against bovine respiratory syncytial virus neutralize the virus in vitro. Procedia Vaccinol 6: 33-38, 2012

87. Tsitoura E, Bibaki E, Bolaki M, Vasarmidi E, Trachalaki A, Symvoulakis EK, Spandidos DA and Antoniou KM: [Comment] Treatment strategies to fight the new coronavirus SARS-CoV-2: A challenge for a Rubik's Cube solver. Exp Ther Med (In Press).

88. Docea AO, Tsatsakis A, Albulescu D, Cristea O, Zlatian O, Vinceti M, Moschos SA, Tsoukalas D, Goumenou M, Drakoulis N, et al: A new threat from an old enemy: Re-emergence of coronavirus (Review). Int J Mol Med 45: 1631-1643, 2020.

89. Lee W, Syed Atif A, Tan SC and Leow CH: Insights into the chicken IgY with emphasis on the generation and applications of chicken recombinant monoclonal antibodies. J Immunol Methods 447: 71-85, 2017

90. Spillner E, Braren I, Greunke K, Seismann H, Blank S and du Plessis D: Avian IgY antibodies and their recombinant equivalents in research, diagnostics and therapy. Biologicals 40: 313-322, 2012.

This work is licensed under a Creative Commons Attribution-NonCommercial-NoDerivatives 4.0 International (CC BY-NC-ND 4.0) License. 